依 頼 論 文

\author{
審美歯科におけるチームプレー \\ 一Esthetic Zone における天然歯・インプラント補綴一
}

行田 克則

\title{
Prosthesis of Intact Teeth and Implants in the Esthetic Zone
}

\author{
Yoshinori Nameta, DDS, PhD
}

抄 録

審美ゾーンと言われる前歯のエリアで患者の満足する結果を得ることはまず困難なことが多い.またそ れを長期にわたり維持していくことはさらに困難である。まず患者の口腔内に装着された補綴物は既存の 隣在歯と調和しなければならない.これを達成するには歯科医師だけでは無理で技工士の力を必要とする. またこれにより審美的満足が得られたとしても次には長期的な安定を達成しなければならない. そのため には歯肉の診断をし, 将来起こりうる歯肉の再生と歯肉の退縮を予測しなければならない.もちろん歯肉 退縮は防ぐべきことは当然である。歯肉の再生は歯槽上線維装置の再配列によりなされるが，オーバーイ ンストゥルメンテーションされた歯根面では起こりにくい. また前歯部のインプラント補綴となるとさら に複雑な治療により，周囲組織を再生させなければならないが，このインプラントの粘膜貫通部分はオー バーインストゥルメンテーションされた天然歯と非常に似た状態であり, 歯槽上線維装置の再生が期待で きない.こうした因子を踏まえたうえで歯科医師，技工士とも患者に向かうことが重要である.

和文キーワード

歯槽上線維装置, 歯肉退縮, インプラント間乳頭

\section{I. 緒言}

審美歯科という用語を安易にとらえれば，短い時間軸 での見た目ということになる。しかし本学会のように口 腔機能を根本的に捉える会ではこのような道理は通用し ない. 審美という用語を筆者も便宜的には用いるものの, その違和感は自身の中でも払拭できないのが事実であ る. 本学会においては機能美といったところが適してい るのかもしれない.

さてこうした機能美を追求することにおいて歯科医師 1 人で達成することはできず，やはり熟練した技工士の 力を借りなければならない. 当院では患者をヒエラルキ 一の頂点と位置づけ, 歯科医師は健康な歯肉の構築を行 い，技工士は隣在歯と調和のとれた補綴物を作るという ことが実際の約束事となっている。したがって最終補綴 の術後を診たときに歯肉の状態が悪ければ歯科医師に責
任があり，逆に歯肉の状態が良いのに補綴物の調和が悪 ければ技工士に責任があるということは，当院では結果 に対する検証として当然のこととなっている．前述のご とく現在の歯科医療において 1 人ですべてを行うこと は難しく当然チームワークが必要となる。本稿では当院 における，こうしたチームプレーの結果を報告したい.

\section{II. 技工士と歯科医師の立場}

1 本のクラウンの修復処置を考えた場合, 歯科医師に とっては比較的簡単な処置である。しかし技工士にとつ てはコストパフォーマンスの点からもそして技術的な面 でも最も難しい仕事となる。したがって技工士はこうし た 1 本の症例をいかに色調を合わせスムースにこなす ことが技量の重要な部分となる。また，こうした苦労を 歯科医師としては十分に理解しておく必要がある (図 1 , 2). 色調を合わせるために, いくつかの理由のもとで隣

上北沢歯科

日本大学歯学部准教授

Kamikitazawa Dental Clinic

Associate Professor, School of Dentistry, Nihon University 


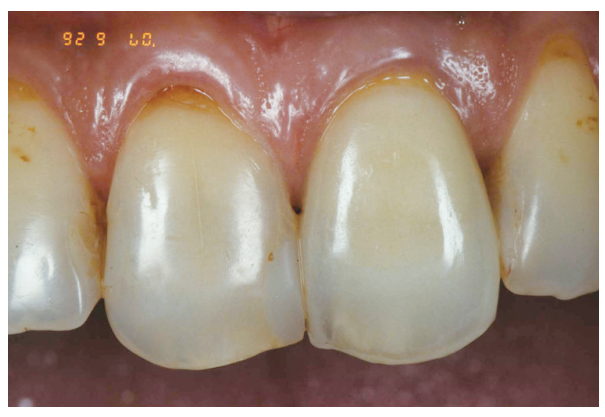

図 16 years after delivering a pfm crown in the left central incisor. Our dental team is satisfied with the result.

左側中切歯に pfm クラウンが装着され約 6 年後の状 態. 技工士は色調, 形態ともに十分な成果を上げた。

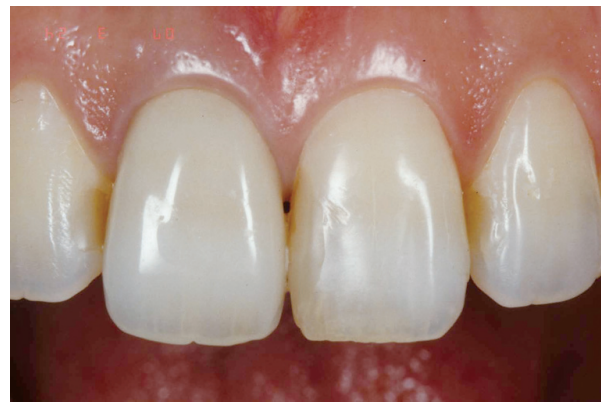

図 2 The pfm crown inserted in the right central incisor. 5 years after the insertion.

右側中切歯に pfm クラウンが装着された。技工士, 歯科医師ともに自分の仕事を確実にこなした結果で ある。約 5 年経過.

在歯を修復対象とすることもあるが，医療の観点からは 決して迎合できることではないことは言うまでもない.

ここに示す $2 つ の$ 症例は隣在歯と調和した pfm クラ ウンの症例であるが，こうした症例を仕上げるには，技 工士は実際に患者を診て写真に記録し，さらにメモを取 り仕上げていかなければならない，もちろん色を解析し ていく能力がなければならない。

\section{III. 天然歯における歯周組織の診断}

\section{1. ブラッシング圧}

患者がブラッシングをしないというのは論外である が，ブラッシング指導をする歯科医師が本当に理想的な ブラッシングをどのように捉えるかは重要である。つま り齵蝕，歯周病の予防という名の下にただ磨くことのみ を啓発する時代は終焉を迎えたと考えるべきである，患 者が無理なく導入でき，また効果的でありさらに為害作 用がないことが重要である。特に筆者はブラッシング圧

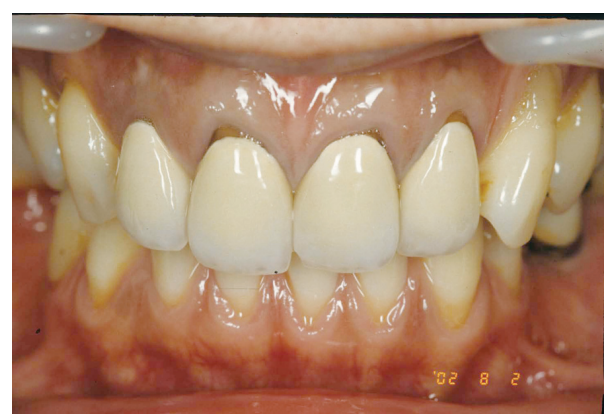

図 3 This patient needed esthetic restorations in her anterior region. Prior to treatment, we should check the tooth brushing trauma.

審美的理由で上顎 4 前歯の再治療を希望した患者で ある。治療に先立ち患者のブラッシング圧が非常に 強いことを見抜かなければ治療は成功しない。
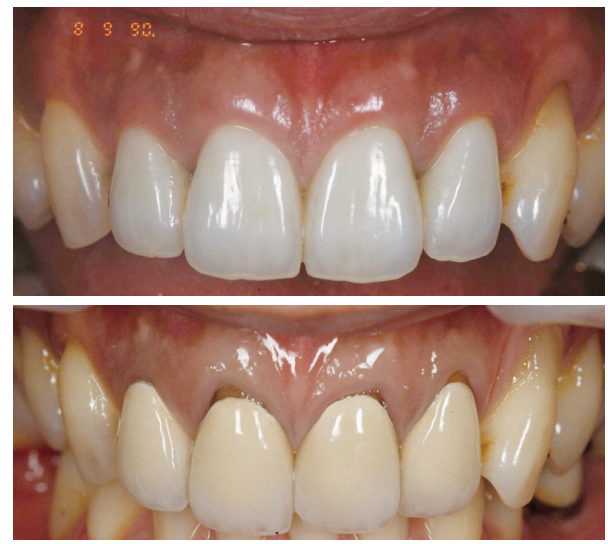

図 4 After avoiding excess pressure to the marginal gingivae, marginal tissue became natural appearance. Before and 4 years later.

ブラッシング圧による退縮であるので，それを改善 すれば術後はより審美的となる。 4 年経過時。
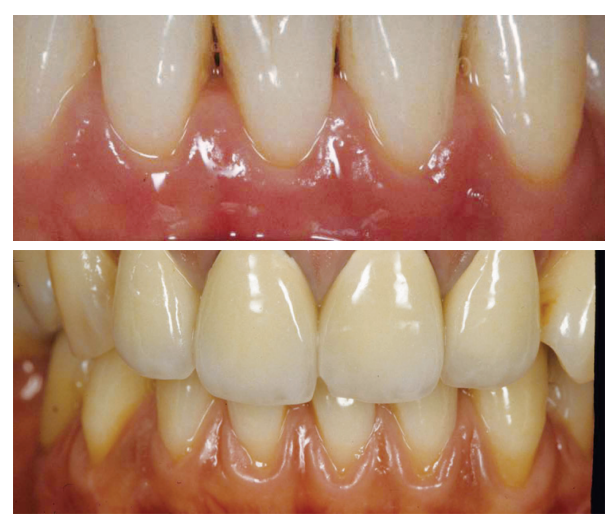

図5 The lower anterior region became natural appearance same as upper jaw.

初診時に認められた下顎前歯のクレフト（下段）は 明らかにブラッシングによる弊害である。治療をす ることなく 4 年後の下顎前歯はクリーピングを起こ している（上段）. 


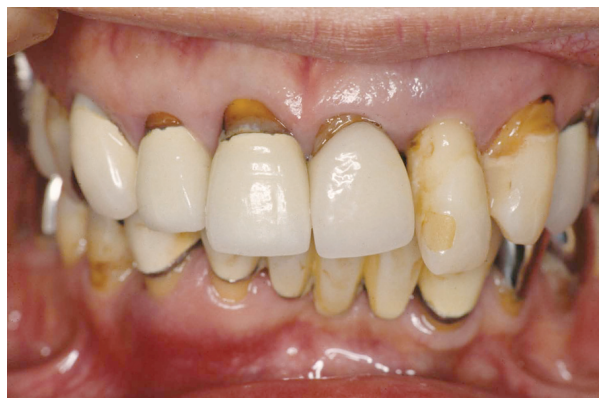

図 6 This patient expected esthetic treatment in her 12 to 23.

上顎右側側切歯から右側犬歯の審美治療を希望して 来院した患者である。予算的な問題でなるべく補綴 範囲が広範にならないことも希望した。

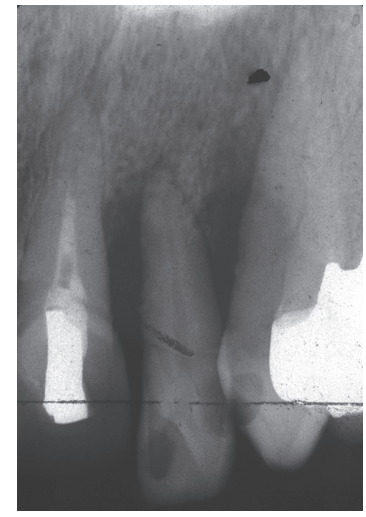

図 7 In spite of the periodontal treatment, the 22 was extracted. The infrabony pocket exists in the medial portion of the 23

左側側切歯は保存予定であったが，抜歯となってし まった。左側犬歯近心には垂直的な骨欠損を認める.
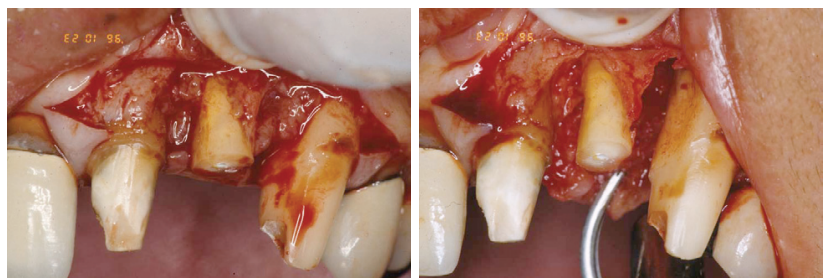

図 8 After raising the flap, granulation tissue was removed by hand instrument.

犬歯近心部の肉芽組織を除去しハンドインストゥル メントで可及的に根面の滑沢化を図った（1996 年 10 月).

を重要な因子と位置づけている。つまり術後に歯肉が安 定するためには過度なブラッシング圧は禁忌であり，術 前にそれを術者が把握していることは必須と考えられる からである，実際の臨床においても修復処置後にブラッ クマージンとなることは決して望ましいことではない.

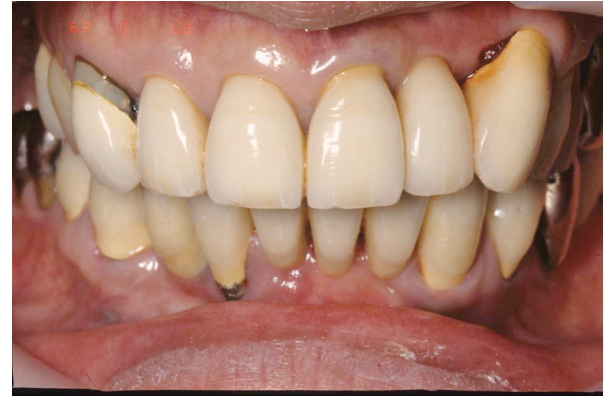

図 911 years after the crown insertion. 5 units of crown delivered No. 12 through No. 23. Only the root planed area (mesial of No.23) was not covered by soft tissue.

術後約 11 年の正面観を示す。ルートプレーニング を行った左側犬歯近心部の軟組織再生が，他の部位 と比較して不良である。
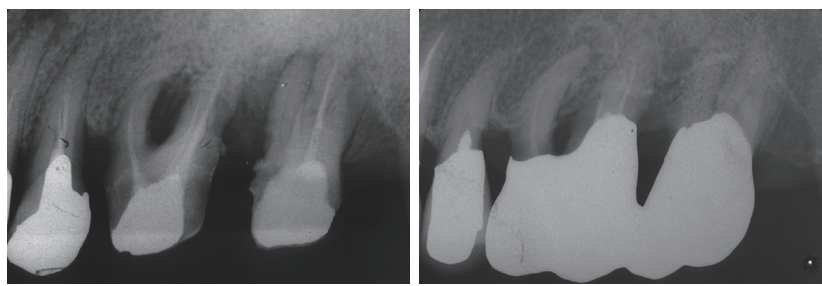

図 10 The posterior region of the same patient. These X-ray films show the bone regeneration during the 11 -year period. 11 years before, only the ultrasonic scaler applied to this region.

同一患者の同時期の左側臼歯部を示す。1996 年(左) と 2007 年（右）である. フラップをあけることに より歯の脱離が疑わ机たので，超音波スケーラーの みのスケーリングを行い保険の範囲のクラウンを装 着した。約 11 年後骨は再生し動摇度は 3 度から 0 度となっていた。

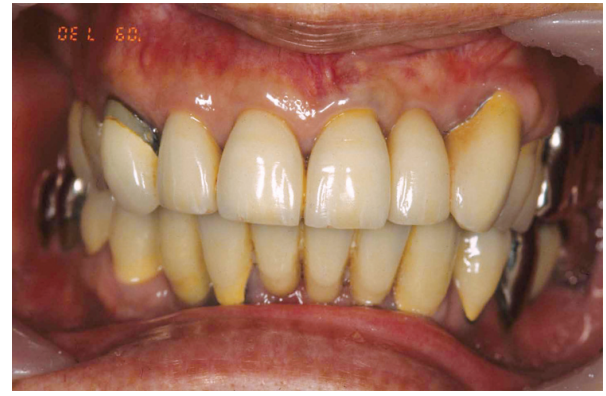

図 1113 years after the operation. The soft tissue regenerated in the mesial potion of the upper left canine. This case shows the over instrumentation results in slower tissue regeneration.

約 13 年後の 2009 年 7 月の状態を示すようやく 左側犬歯近心部の軟組織の再生が認められるように なった。筆者は過度のルートプレーニングは歯根膜 を除去し，歯槽上線維装置のアンカリングを阻止す ることを手術当時は想像もしなかった。 


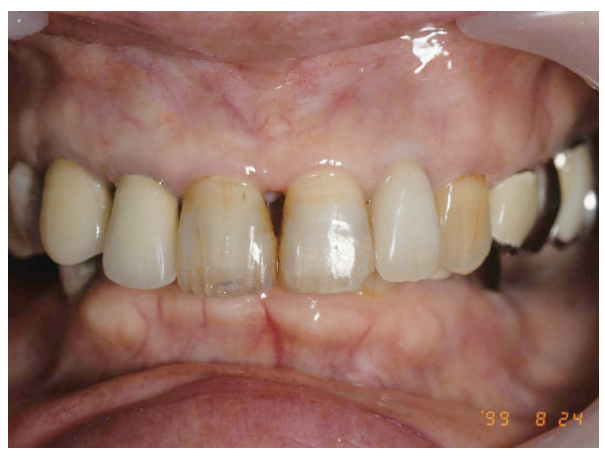

図 12 Initial situation in the 62-year-old female patient. This patient lost the inter-dental papila of central incisors.

この患者は，初診時なぜ歯間乳頭が缺失しているの か理由がわからなかった。じきに再生するだろうく らいに考えていた。

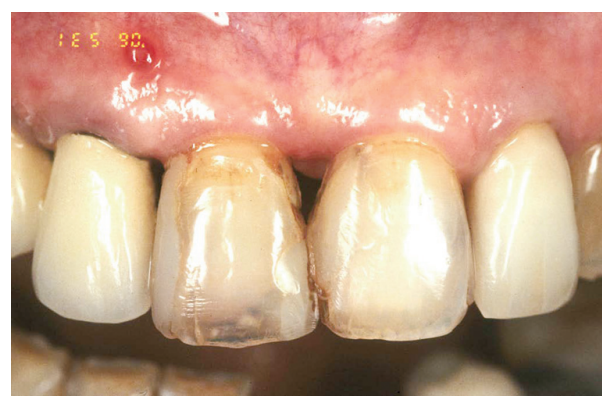

図 137 years after the initial situation.

約 7 年後の状態である. 再生の兆候どころかプラー クの格好の溜まり場となっている.

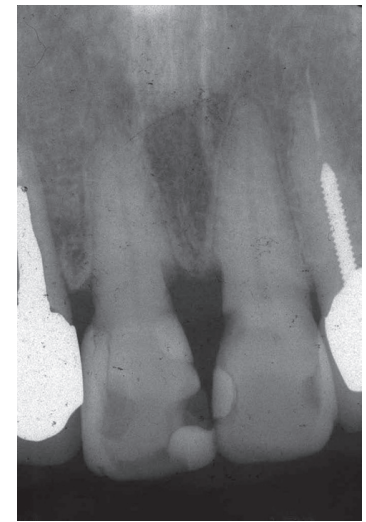

図 14 From the X-ray view, the root surface of central inscisors was removed by instrument. This concave corresponds to the black triangle.

再びX 線写真を精査したところ, 骨縁上に多分ハン ドスケーラーによると思われる大きな削り込みが認 められた。歯根膜のみならず象牙質までも削除され た歯根表面には軟組織再生の場は存在しない.

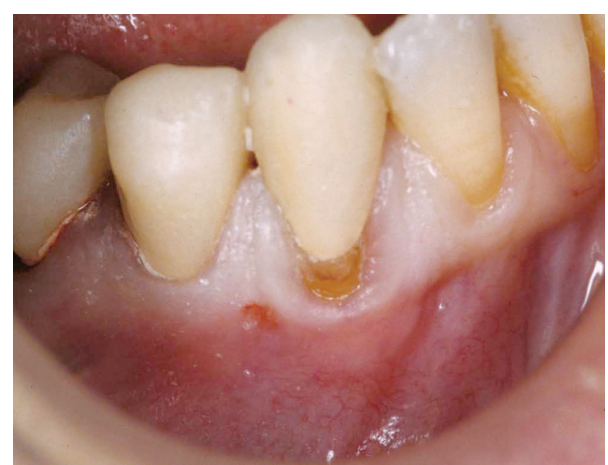

図 15 Submarginal tissue receded in the lower right canine.

1997 年下顎右側犬歯部に歯肉退縮を認める。十分 な原因を追及することもなく歯根面の被覆に踏み切 つた.

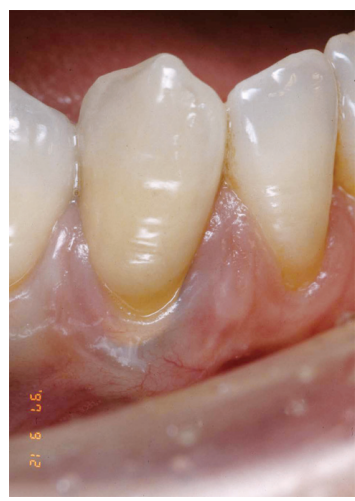

図 16 The exposed root was covered by the adjacent tissue.

有茎弁側方移動により根面被覆を行ったが，歯肉の 厚みは薄く補綴物のマージン部が透けて見える状態 である(1997 年 9 月).

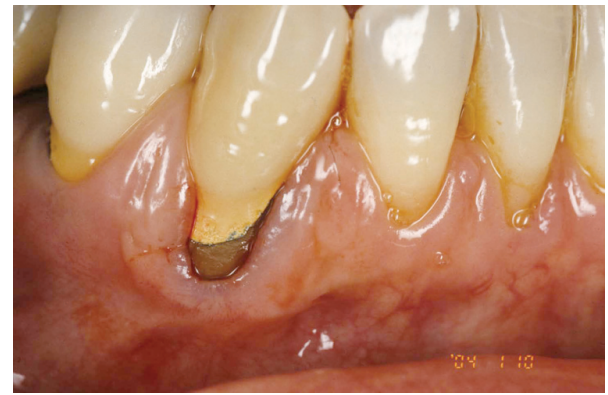

図 177 years after the operation, the covered root exposed again. This recession was caused by the thin thickness of the recipient site soft tissue.

しばらく患者の来院がなかったが，術後 7 年目に来 院したときはマージン部が完全に露出するほど退縮 が起こっていた。この時期に患者に理解を得て再手 術を行った。 


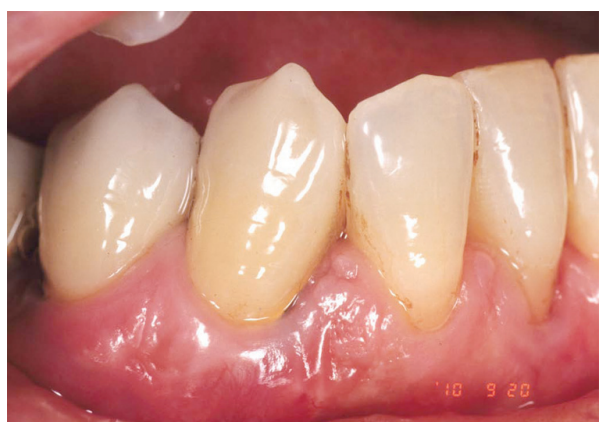

図 18 To obtain the full thickness of tissue, a second operation was planned with bone grafting. Results at 6 and half year after the second surgery are shown. The second surgery achieved good esthetic result. This canine pfm crown delivered 13 years ago.

再手術をしてから約 6 年 6 力月が経過したが，近心 のマージン露出がわずかに認められるものの審美的 に問題はない. 1 回目の手術は歯肉のみの移動を行 つたが，2回目の手術は骨のボリュームを獲得する ためグラフト材の填入を行ったためにこのような結 果が得られたと考えられる。Pfm クラウン装着から 13 年経過.

特に前歯部でのマージン露出は自然観を失う第一の因子 と考えられる。

辺縁歯肉で隠されたマージン部を強圧のブラッシング で連日擦ってしまえば，歯肉は簡単に退縮し，マージン は簡単に露出してしまう。したがってブラッシング圧が 過度である兆候を示す，歯肉退縮，歯肉のスクラッチ， 過度な角化傾向，白すぎる歯肉，歯肉クレフトなどが認 められたら術前にブラッシング圧のチェックを行い，患 者には改善するように啓発する必要がある（図 $3 \sim 5$ ).

\section{2. ルートプレーニングと歯根膜}

補綴前処置として歯石の除去は重要である。また歯石 除去の一環としてルートプレーニングを行うことも重要 である。しかしルートプレーニングにおけるオーバーイ ンストゥルメンテーションは注意をしなければならな い. 理想的には選択的に歯石のみ除去ができることが望 ましく，歯根面をプレインつまり平滑な状態にする必要 があるか否かは, 今後議論するに十分な臨床術式である。 歯根面には歯根膜がありここに入り込むシャーピー線 維，オキシタラン線維などによって歯槽骨，結合組織が 作られるといっても過言ではない. つまりルートプレー ニングによって歯根膜を除去してしまうと歯肉は退縮を 起こし，歯肉の再生は起こらないこととなる，前述のよ うに歯肉を健康にすることが歯科医師の仕事だとする と，その健康にする歯肉の㳖失は審美的要求をはじめか

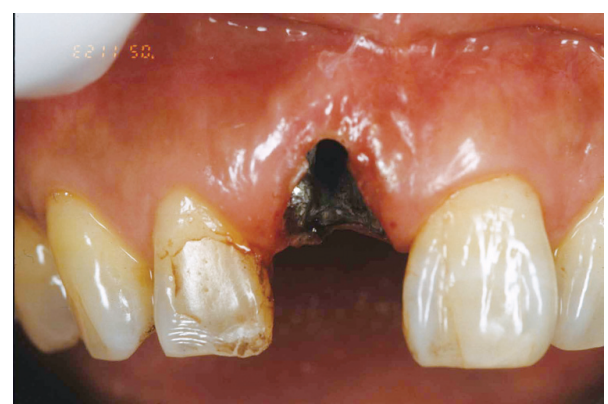

図 19 Initial situation in the 60-year-old female patient. She needed implant prosthesis in her right central incisor.

破折歯根のためインプラント治療を希望した患者の 初診時の状態を示す。

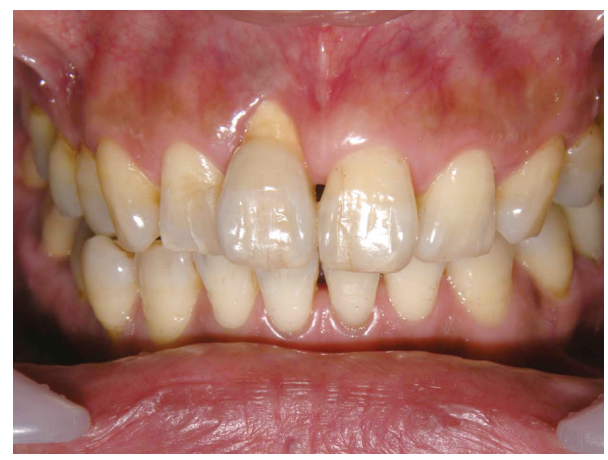

図 20 The author chose conservative treatment. The pfm crown delivered in her right central incisor. 結局インプラント治療は行わず pfm クラウンを装着 した.

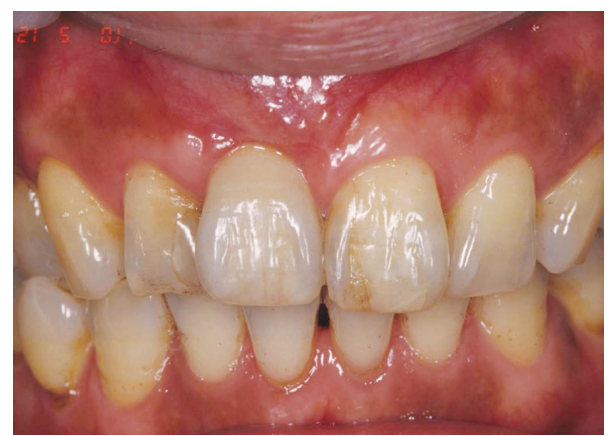

図 21 After delivering the pfm crown, the tissue grafting planed with the bone grafting. Results at 4 and half year after the surgery are shown.

クラウン装着後グラフト材を填入し, 歯肉のボリュ 一ムを確保し，歯肉を歯冠側に移動した。手術は最 終補綴物装着とほぼ同時期に行った。術後 4 年 6 力 月経過したが安定していると考えている.

ら否定することにもなりかねないのである.

今回提示した症例は筆者自身がハンドインストゥルメ 


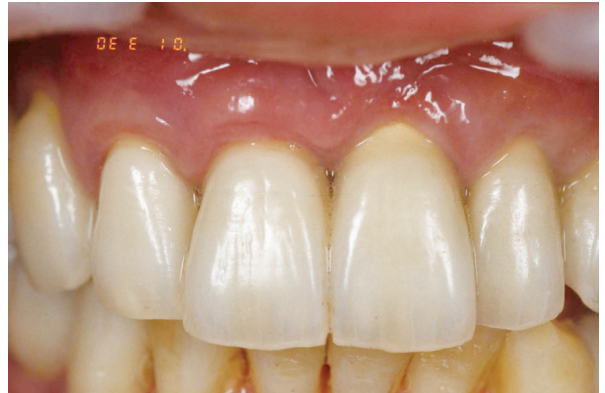

図 22 Two implant prostheses delivered to upper two central inscisors.

上顎中切歯 2 本はインプラント補綴で左右側切歯は 天然歯に pfm クラウンを装着した (2001 年 3 月).

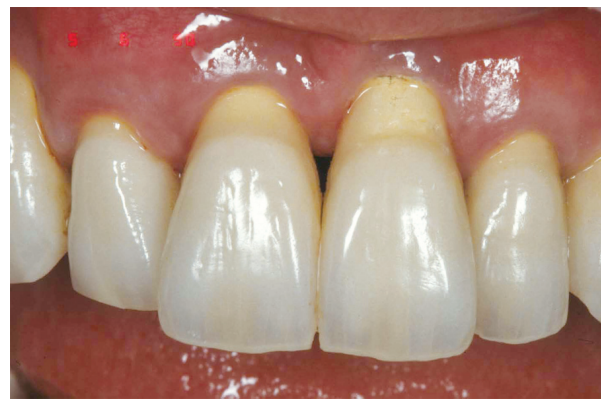

図 235 years after the operation. The submarginal tissue receded about $2 \mathrm{~mm}$.

約 5 年経過時. 患者はブラッシング圧が強く，マー ジン部に退縮を認めるが，特にインプラント補綴の 中切歯が顕著である.

ントで過度のルートプレーニングを行った部位には歯肉 の再生が起こりづらいことを示すと同時に，超音波スケ ーラーのみを使用した同一患者の臼歯部には骨の再生ま でもか認められていることを示している（図6１1）.

また前医により過度にルートプレーニングされた歯根 面相当部の歯間乳頭は長期的な観察においても再生の兆 候が認められない（図 12〜14).

\section{3. 辺緑歯肉の厚み}

辺縁歯肉に厚みがあることは歯肉退縮が起こりづらい ことが示されてきた. Flat-thick と言われる歯肉では歯 肉が退縮しづらく scalloped-thin と言われるタイプで は退縮が起こりやすいと言われている，歯肉の厚みをか えることができれば予後は安定し歯肉退縮から起こるマ ージン露出による審美障害も回避できる。

本症例は歯肉退縮を有茥弁側方移動術にて根面被覆を 行ったが，術後約 6 年後に再び歯肉退縮が起こってし まった。原因としては歯肉の厚みの確保が不十分であっ たためと考えられた。患者に承諾を得，再度手術を行つ
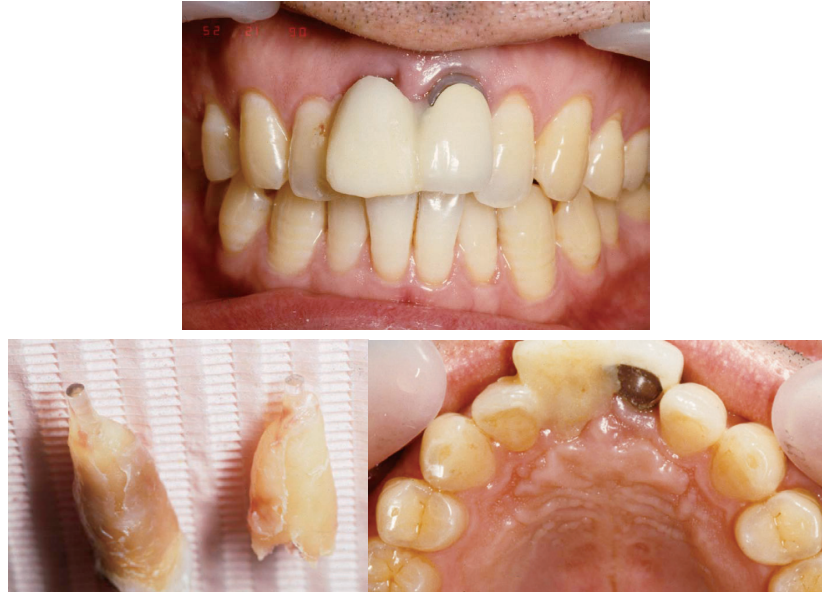

図 24 Two central incisors removed by the injury. 歯内骨内サファイアインプラントが装着された後, 歯根吸収により歯の動摇を認めた患者の上顎中切歯 にインプラント補綴を行う術前の状態である。

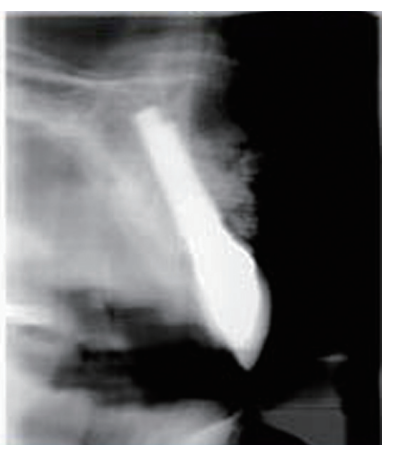

図 25 Prior to the insertion of fixtures, the bone grafted in the front area of the fixtures.

インプラント埋入時に注意した点は賛側寄りになる べく多くのグラフト材を填入することにあった。

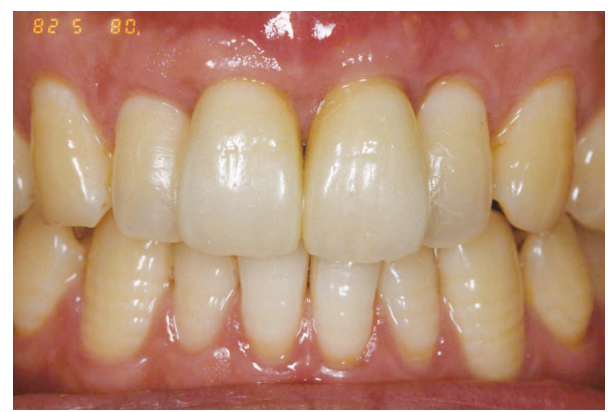

図 26 Bone grafting resulted in full thickness of marginal tissue.

最終補綴よりまだ 1 年であるが歯肉の厚み，正確に は骨の厚みが確保されている。

た。このとき移植材を用い歯槽骨の厚みを確保すること で，歯肉全体のボリュームを増やした（図 $15 〜 18$ ). 


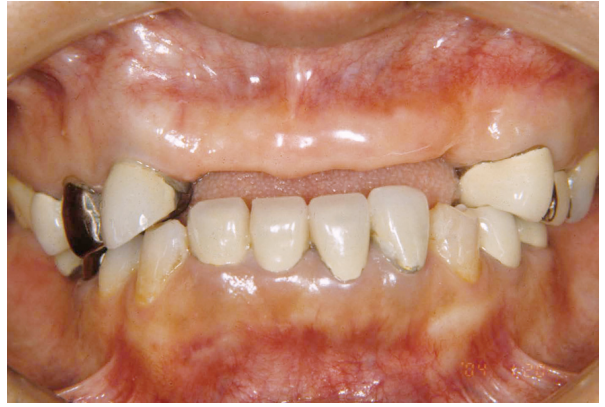

図 27 Initial consultation of the 46-year-old female patient. She expected esthetic result by using implant prosthesis.

上顎前歯部を 5 本欠損した患者の初診時である。患 者はインプラント補綴を希望し当院に紹介された。

また次の症例は歯根破折で歯肉退縮の起こった症例に 対し, 最終補経物装着後に歯肉の歯冠側移動とともに移 植材の填入を行い歯槽骨の厚みを確保した（図 19 21).

歯肉の厚みを確保するか，歯槽骨の厚みを確保するか により予後に若干の違いが考えられるが筆者は歯槽骨の 厚みを確保することが多い。また臨床術式の優位性もあ ると考えている.

\section{IV.インプラントにおける周囲組織の診断}

\section{1. ブラッシング圧}

インプラント補綴においてもブラッシング圧は重要と なるが，天然歯のように再生傾向つまりクリーピングア タッチメントは認められないか，認められたとしてもわ ずかである。そして基本的には歯肉退縮傾向を継続的に 起こすと考えてよいであろう．特に元来歯槽骨の薄い前 歯部の連続埋入に関してはその傾向は強い。単独歯欠損 や臼歯のインプラントにおいては必ずしも歯肉退縮が継 続的に起こるわけではないが，これはもとからの骨の厚 みや隣在天然歯の歯槽上線維によって二次的に守られて いるだけなので，何か一つの条件が欠けるだけで歯肉退 縮は起こりやすくなる．したがってインプラント周囲の プラークコントロールは繊細さを加味したうえで患者に 指導したいところである。

インプラント周囲の生物学的幅径について論じられる ことがあるが，金属上に結合組織性付着が起こるわけは なく，チタンにオステオインテグレーションした骨の歯 冠側の組織はすぐ上皮付着の形態をとるはずである。し たがってインテグリンやそれに付随するラミニンなどの 蛋白による付着と，中間径フィラメントなどのテンショ
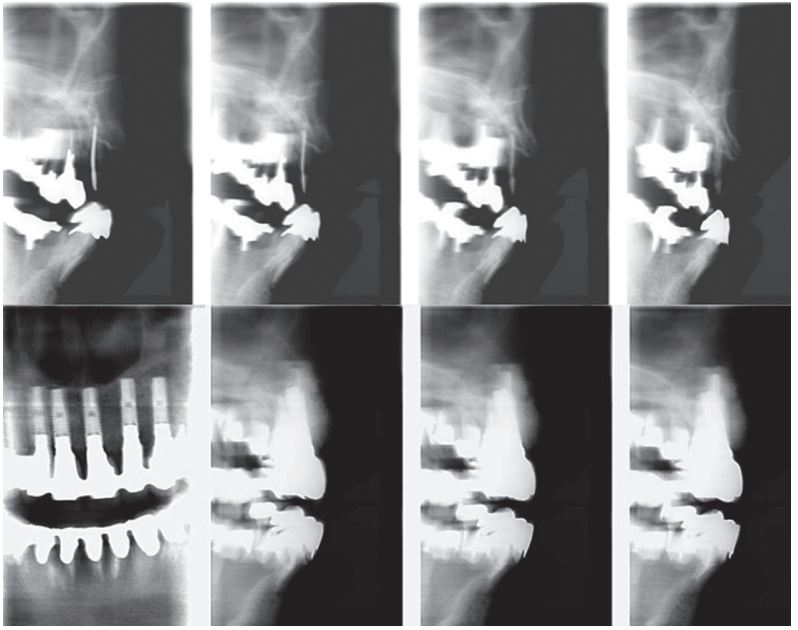

図 28 Cross section showing before and after the operation.

上段が術前，下段が術後であるが唇側方向のグラフ ト材が十分に維持されていることが観察できる。こ のグラフト材を維持することが前歯部インプラント 補綴の必須条件となる。

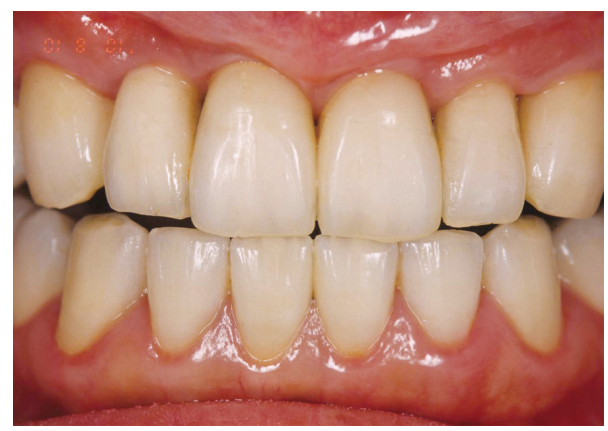

図 29 Results at 4 years after the operation. 5 implants were inserted in the esthetic zone. The patient was satisfied with the result.

最終補綴物装着より約 4 年であるが，口腔前庭の動 きに伴うインプラント補綴物の周囲組織の動きは装 着直後と比べかなり減少した。患者も術者も審美的 結果に満足している.

ンなどにより形成されるインプラント周囲組織は，強い 再生力も強度という点からも十分とは考えづらい.

同じブラッシング圧でブラッシングを行ったとしても インプラント補綴周囲での歯肉退縮は顕著となるが，こ れは組織学的にみて当然の結果である（図 22，23）。

\section{2. 歯肉の厚みではなく歯槽骨の厚み}

天然歯において歯肉退縮を防ぐには歯肉あるいは歯槽 骨の厚みのどちらかを確保することが重要であることは 前述の通りである。しかしインプラント周囲組織におい ては歯肉の厚みより歯槽骨の厚みを優先させることが重 


\begin{tabular}{|l|}
$\quad$ 歯肉の構造 \\
$*$ 上皮 \\
$*$ 固有層 \\
$*$ 歯槽上線維装置 \\
$*$ 血管 \\
$*$ 神経
\end{tabular}

図 30 Basic structure of the gingival. 組織学的に歯肉の基本構造を示す。

\section{歯肉固有層について}

＊構造的にはコラーゲン原線維のほとん どは歯槽上線維装置を構成する線維 束に組み込まれている

*正常時には選択的方向性を持つ線維 束へと組織化されている

Referenced from Schroeder H.E.

図 31 Characteristics of the supra-alveolar fiber apparatus.

Schroeder による歯槽上線維装置の特徵を示す.
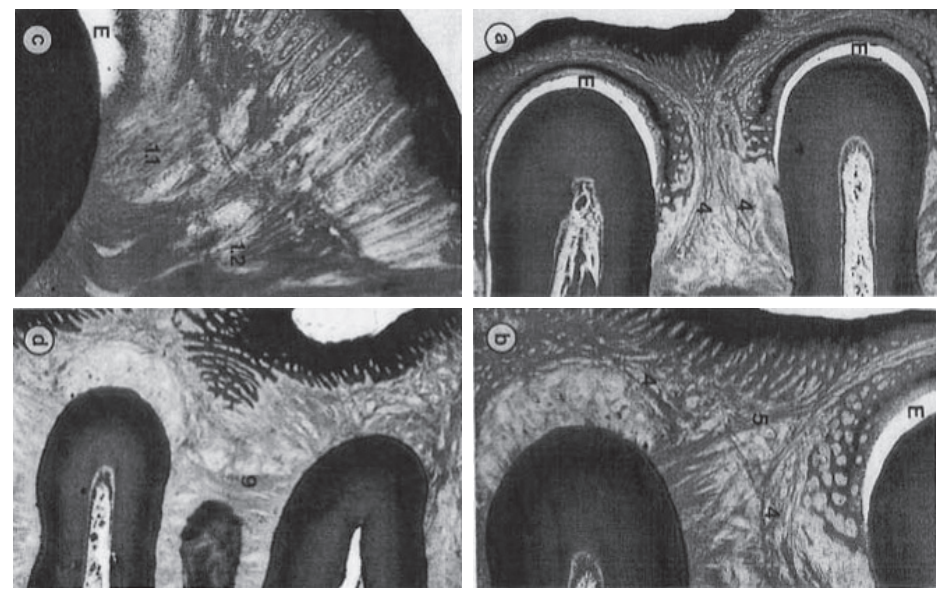

Referenced from Schroeder H.E.

図 32 According to Schroeder, the supra-alveolar fibers arranged constant.

Schroeder が示した歯槽上線維装置の走行であるが，一定の 方向性があることは明確である。

要であると筆者は考えている (図 $24 \sim 26)$. 歯肉の厚 みを確保するために C.T.G（結合組織移植）を行うこ とも報告されるが，インプラント周囲は血管組織が少な く細胞成分に乏しいためこうした組織を恒久的に維持さ せることは難しく 10 年以上といった長期的観念にみる と有効な手段とはならないと考えられる。またインプラ ントの粘膜貫通部には金属との有機的な結合がないこと は前項で述べた通りで，天然歯の歯槽上線維が形成する 付着歯肉はこの部分には存在しないこととなる．臨床上 あたかも付着歯肉が存在するかにみえる場合もあるが, 構造上の付着ができる場所が実在しないので, 天然歯に みられる本来の付着歯肉とは異なり, 安定している歯肉 にはなり得ないのである.

そこで元来歯槽骨の薄い前歯部に連続するインプラン
トを埋入する際にはインプラントの唇側部分に多くの骨 を造成するようにし，骨内の血管を確保すると同時に， その骨の厚みにより, 口唇, 煩粘膜の動きがインプラン 卜補綴の周囲歯肉に直接伝わる動きを二次的に規制する 必要がある。現在では前歯部インプラント埋入に際して 口蓋側寄りに位置づけすることが一般的になろうとして いるが，理由は前述したことと同一である。

症例は特に唇側根尖部での骨造成を行ったものである が，口腔内写真を撮影するために，口角器などで強く口 唇を牽引すると, 辺緑歯肉が動くことか観察される。し かし $3 \sim 4$ 年経過したものではその辺縁歯肉の動きも わずかになることが筆者の臨床的観察から明らかになり つつある(図 $27 〜 29$ ). 


\section{歯槽上線維装置(天然歯)}

1歯一歯肉線維

\section{2歯骨膜線維}

3歯槽歯肉線維

4環状、半環状線維

5歯肉横断線維、歯肉間線維

6乳頭間線維

7骨膜歯肉線維

8環状間線維

9歯間水平線維

2005年QDT行田克則
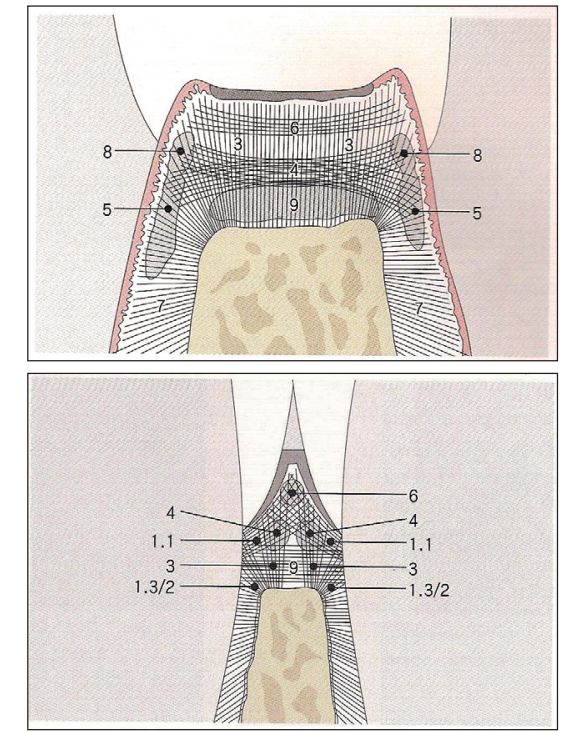

図 33 Structure of the supra-alveolar fiber.

筆者の示した歯槽上線維装置の和訳であり，2005 年の QDT に掲載 された。

\section{結合組織 Color Textbook of Histology Garner L.P. より}

\section{＊疎性結合組織}

* 密性結合組織

\section{1密不規則性結合組織}

(dense irregular connective tissue)

\section{2密規則性結合組織}

(dense regular connective tissue)

1) 膠原線維

2) 弾性線維性

図 34 Classification of connective tissue.

Gartnerの示した結合組織の分類である.

\section{3.インプラントの骨吸収}

天然歯同様インプラントが機能することにより歯槽骨 は吸収しないとの考えは, Araujo ${ }^{1,2)}$ の論文によって 簡単に払拭されてしまった。つまり歯根表面由来の線維 により構成される bundle bone は歯の喪失とともに失 われるわけである。義歯床の下で骨吸収が起こることと インプラント周囲で骨が喪失することとは非常に共通し た現象であることがわかる。しかし義歯床下の歯槽骨の 吸収も患者によって異なり一様ではない。適合，機能，
振動の伝達がその一因と論じても確証はない.インプラ ント周囲も現段階では不明な点が多く存在することは否 めない. したがって臨床的には吸収しても問題が起こり づらい臼歯部と，唇側の骨が吸収することにより審美的 影響が出やすい前歯部では，治療当初からその治療計画 を変える必要があるだろう。

また歯根面から派生する歯槽上線維群がないことが義 歯とインプラントは共通であることも忘れてはならない.

\section{V．歯周組織と周囲組織一天然歯とインプラント一}

天然歯の歯肉の構造は以下のように分類できる。つま り上皮，固有層，歯槽上線維装置，血管そして神経であ る(図 30)。特にこの中でも歯肉の形態を支持している のは歯肉固有層と考元られる。歯肉固有層の特徵として Schroeder ${ }^{3}$ は以下のように述べている(図31,32)。「歯 肉固有層のコラーゲン原線維のほとんどは歯槽上線維装 置を構成する線維束に組み込まれ，選択的方向性をもつ ように組織化されている」つまり天然歯においてコラー ゲン原線維が歯槽上線維装置を構成する際（図 33），特 に歯根面から方向性を持ち派生することにより，辺縁歯 肉や歯間乳頭の形態が決まると考えられる。一方インプ ラントにおいてはその方向性をもたせる歯根面に相当す 
る部位が存在しないため, Berglundh ${ }^{4)}$ の指摘するよ うに不規則な目の粗いコラーゲン線維がアバットメント に平行に走るという結果をもたらすこととなっている.

解剖学的に結合組織を分類すると疎性結合組織と密性 結合組織ということになる。この歯肉固有層は密性結合 組織の範疇に入ると筆者は考えるが，この密性結合組織 はさらに密不規則性結合組織 (dense irregular connective tissue) と密規則性結合組織 (dense regular connective tissue) に分類される（図 34). この分類で前者をインプラントの周囲組織，そして後者 を天然歯の歯周組織というように当てはめてみると非常 に理解しやすい.

つまりコラーゲン原線維に方向性をもたすことは歯根 膜により委ねられていることは論を俟たないであろう。 こうした理由がインプラント周囲の軟組織再建を臨床上 困難にしていると言えよう。

\section{VI、まとめ}

読者の皆さんに「なぜプロービングは $25 \mathrm{~g}$ で行うの ですか」という質問をさせていただきたい. 科学には常 に疑問をもつことが必要でそれに対し, 反証あるいは証 明がなされていく，何の疑問をもたずにプロービングを 行うのはもちろん科学的ではないという意味から質問さ せていただいた。しかしこの $25 \mathrm{~g}$ というのはチューリ ッヒ大学の研究グループ5) が 8 人の臨床家に, 優しい 力で健康な歯肉にプロービングしてもらい, その平均值 から求めた值であるとすれば，科学的根拠もないのかも しれないし，私は愚問を投げかけたのかもしれない。こ の值はかつて歯肉溝底を示す值であると信じられていた が，後に反証として結合組織の約 $0.5 \mathrm{~mm}$ 手前を示す こととわかった ${ }^{6-8)}$. それが示されるまで約 10 年がか かり，その間にはプロービング值の範囲でマージンを決 定する歯肉構内マージンという言葉すら生まれた。アメ リカ歯周病学会もプロービング值を正しく修正するのに 約 10 年を費やした. 1977 年から 1986 年までの話で ある。専門医認定医の講師として登壇するにあたりいま だに 1986 年の考えで臨床を行う専門医がいては困ると いう意味も込めた質問でもあった。また原著論文に目を 通してもらいたいという気持ちもあった。今回述べさせ
ていただいたインプラントにおける前歯部補綴にはいま だ不明な点が多いのは，当時のプロービングのコンセプ トとなんら変わらないかもしれない. インプラントの粘 膜貫通部金属に結合組織は有機的につかないことは自明 の理である. 光学顕微鏡の観察から結合しているという ような解説をし, それをインプラントの生物学的幅径と いうならば，聴講された補経学会員には冷静にそれを電 子顕微鏡で観察した論文を探していただきたい.

\section{文献}

1) Araujo MG, Lindhe J. Dimensional ridge alterations following tooth extraction an experimental study in the dog. J Clin Periodontol 2005; 32: 212-218.

2) Araujo MG, Sukekava F, Wennstrom JL, Lindhe J. Ridge alterations following implant placement in fresh extraction sockets an experimental study in the dog. J Clin Periodontol 2005; 32: 645-652.

3) Schroeder HE (下野正基ほか)。シュレーダー歯周組織。 東京: 医歯薬出版; 1989, 298.

4) Berglundh T, Lindhe J, Jonsson K, Ericsson I. The topography of the vascular systems in the periodontal and peri-implant tissues in the dog. J Clin Periodontol 1994; 21: 189-193.

5) Gabathuler H, Hassell T. A pressure-sensitive periodontal probe. Helv Odont Acta 1971; 15: 114-117.

6) Armitage GC, Svanberg GK, Loe H. Microscopic evaluation of clinical measurements of connective tissue attachment levels. J Clin Periodontol 1977; 4: 173-190.

7) Ezis I, Burgett F. Probing related to attachment levels on recently erupted teeth. J Dent Res 1978; 57: 307 (Abstract No.932).

8) Robinson P, Vitek RM. The relationship between gingival inflammation and resistance to probe penetration. J Periodontal Res 1979; 14: 239-243.

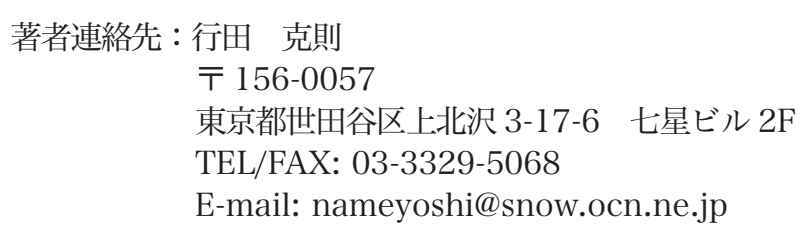




\title{
Prosthesis of Intact Teeth and Implants in the Esthetic Zone
}

\author{
Yoshinori Nameta \\ Kamikitazawa Dental Clinic \\ Associate Professor, School of Dentistry, Nihon University
}

Ann Jpn Prosthodont Soc $3:$ 108-118, 2011

\section{ABSTRACT}

To achieve satisfactory esthetic results in patients is an important challenge for dentists. To maintain esthetic results is difficult from the view of prevention of prosthesis collapse and of marginal tissue recession.

First, the dentist and dental technician deliver the final restorations that harmonize with the esthetic zone of the patient. Second, the dentist attempts to prevent marginal tissue recession after delivery of the final restorations. To maintain healthy gingival tissue is also difficult, so it is necessary to understand the natural features of tissue surrounding intact teeth and implants.

This article discusses differences between intact teeth and implants. The regeneration characteristics of supraalveolar fiber apparatus surrounding the tooth and implant, also reveals the importance of the portion of penetrating mucosa that connects to the root or prosthesis directly. Some clinical approaches to the above issues are presented.

\section{Key words}

supra-alveolar fiber apparatus, marginal tissue recession, inter-implant papillae 